\title{
Mudanças simbólicas: análise discursiva das transformações identitárias e espaciais em uma feira*
}

\author{
Symbolic Changes: discursive analysis of identity and spatial transformations in a \\ fair
}

Thiago Duarte Pimentel ${ }^{1}$

Alexandre de Pádua Carrieri

Alfredo Rodrigues Leite-da-Silva ${ }^{3}$

Cláudio Borges Abate Júnior ${ }^{4}$

Agradecemos Pablo Alexandre Gobira de Souza-Ricardo pela revisão técnica e gramatical deste artigo.

\section{Resumo}

Este trabalho, apoiado na Análise do Discurso (AD) (FIORIN, 1988), tem por objetivo analisar a transformação da identidade da Feira de Arte, Artesanato e Produtores de Variedades de Belo Horizonte. Analisando um período de 36 anos que perfaz sua história, pode-se observar as mudanças envolvidas tanto na identidade desse evento, considerado como uma instituição mineira, quanto na ocupação dos espaços físicos e simbólicos. A partir da coleta de documentos do Arquivo Público da Cidade de Belo Horizonte, na consulta a reportagens de jornais e em entrevistas abrangendo os representantes da feira junto à Prefeitura Municipal de Belo Horizonte, reconstituiu-se a transformação da identidade. Nessa (re)construção histórica foi possível evidenciar a existência de um grande percurso semântico denominado: transformação de identidade que, por sua vez, estrutura-se em dois subconjuntos: a) o da formação de identidade; e b) o da clivagem identitária. Por fim, os discursos coletados indicaram a grande transformação identitária sofrida - uma Feira de Arte e Artesanato criada como forma de expressão de um movimento artístico e cultural que, a partir da incorporação de novas subjetividades, e (re)apropriação do espaço físico e simbólico, tornou-se um espaço integrado à lógica do que se denomina hoje de "mercado".

Palavras-chave: identidade; espaço; organizações; análise do discurso

\begin{abstract}
The objective of this work, which is based on Discourse Analysis (DA) (FIORIN, 1988), is to analyze the identity transformation of Feira de Arte, Artesanato e Produtores de Variedades de Belo Horizonte. We analyze a longitudinal period of 36 years that embraces its whole history. We observed the changes involved both in the identity of this event and in its physical and symbolic spatial occupation. Based on the documents collected in Public City Archive of Belo Horizonte, journals and interviews with the fair managers, we verified the transformation of the fair's identity. In the historical (re)construction of this organization it was possible to observe the existence of what we called an identity transformation which, in its turn, is structured on two subsets: a) the identity formation; and b) identity- cleaving. At least, discourses colleted show us a huge identity transformation: a fair that was created as an artistic and cultural kind of movement, which, with the incorporation of new subjectivities, and the physical and symbolic spatial (re) appropriation, became a space integrated to the logic of "consumption market".
\end{abstract}

Keywords: identity; space, organization; discourse analysis

\footnotetext{
${ }^{1}$ Mestrando em Administração. Graduado em Turismo pela Universidade Federal de Minas Gerais. Pesquisador do Núcleo de Estudos Organizacionais e Simbolismos (NEOS) - Centro de Pós-Graduação e Pesquisas em Administração (- CEPEAD). Endereço: CEPEAD / Faculdade de Ciências Econômicas / Universidade Federal de Minas Gerais, Rua Curitiba, 832/1202, Centro, Belo Horizonte - MG - Brasil - CEP : 30170 - 120. E-mail: xtdp@cepead.face.ufmg.br

${ }^{2}$ Doutor em Administração pela Universidade Federal de Minas Gerais. Professor - Centro de Pós-Graduação e Pesquisas em Administração - CEPEAD / Faculdade de Ciências Econômicas - FACE / Universidade Federal de Minas Gerais - UFMG - Endereço: CEPEAD / FACE / UFMG, Rua Curitiba, 832/1202, Centro, Belo Horizonte - MG - Brasil - CEP : 30170-120. E-mail: alexandre@cepead.face.ufmg.br

${ }^{3}$ Mestre em Administração pela Universidade Federal do Espírito Santo. Doutorando em Administração - Centro de Pós-Graduação e Pesquisas em Administração - CEPEAD / Faculdade de Ciências Econômicas - FACE / Universidade Federal de Minas Gerais - UFMG. Endereço: CEPEAD / FACE / UFMG, Rua Curitiba, 832/1202, Centro, Belo Horizonte - MG - Brasil - CEP : , 30170 - 120, E-mail: arls@cepead.face.ufmg.br

${ }^{4}$ Graduando em Administração pela Universidade Federal de Minas Gerais - Faculdade de Ciências Econômicas - FACE / Universidade Federal de Minas Gerais UFMG. Endereço: FACE / UFMG, Rua Curitiba, 832/1202, Centro - Belo Horizonte - MG - Brasil - CEP : 30170- 120. E-mail: cborges@face.ufmg.br
}

Artigo recebido em agosto de 2005 e aceito para publicação em novembro de 2006 


\section{Introdução}

Este artigo, apoiado na análise do discurso (AD) (FIORIN, 1988), tem por objetivo analisar a transformação da identidade da Feira de Arte, Artesanato e Produtores de Variedades de Belo Horizonte, considerada outrora uma "Woodstock mineira", e atualmente um "Camelódromo" a céu aberto. Analisando sua história, que compreende o período de 1969 até 2005, podemos observar as transformações envolvidas tanto na identidade dessa instituição (evento) e de seus comerciantes, quanto na ocupação dos espaços físicos e simbólicos. Percebeu-se como as transformações provocaram um forte desenraizamento, ou melhor, uma desterritorialização das pessoas e das significações construídas historicamente na Feira. Esse movimento levou os comerciantes a remodelarem suas práticas comerciais e administrativas em função de uma nova lógica de atuação: a da racionalidade econômica do mercado, o que, por sua vez, traduziu-se em diferentes formas de ocupação do espaço, na construção de novas identidades organizacionais e na adoção de novas formas de comportamento e de estratégias implementadas, tanto de produção quanto de venda de seus produtos.

Por constituir um espaço plural e representativo de várias vozes, a "Feira Hippie", como popularmente é conhecida, congrega-as pela característica peculiar de promover uma indissociabilidade entre os diferentes tipos de pessoas, de classes sociais e de visões de mundo (GUERRA, 2002). Assim, constroem-se e reconstroem-se, modificam-se e transmutam-se relações sociais e culturais em econômicas e administrativas, gerando implicações na identidade da Feira e nos espaços físicos e simbólicos que ela abrange. Tais relações e suas materializações num dado espaço são o escopo deste artigo.

Para a abordagem empírica do tema, procedeu-se a um estudo longitudinal da história da Feira. Utilizou-se o método de pesquisa qualitativa baseado na análise do discurso (AD). Essa técnica foi aplicada a partir da coleta de 98 documentos, como os encontrados no Arquivo Público da Cidade de Belo Horizonte, na consulta a reportagens de jornais comerciais, dos jornais da própria Feira, assim como em entrevistas abrangendo os dois principais representantes da Prefeitura Municipal de Belo Horizonte, diretamente responsáveis pela administração da Feira. As entrevistas visam complementar a escassez de documentos oficiais da prefeitura sobre o objeto em estudo. A ênfase na análise documental, concordando-se com Rowlinson e Procter (1999), justifica-se, pois os documentos que relatam a história das organizações e instituições são tão importantes quanto qualquer entrevista. Além disso, para a $\mathrm{AD}$ os documentos são fontes primárias de estudo.

Os discursos coletados, escritos e falados, indicaram a ocorrência de uma grande transformação identitária: uma feira de artes e artesanato criada sob o movimento artístico e cultural que, com a (re)criação de novas subjetividades e a (re)apropriação do espaço físico e simbólico por parte dos antigos e pela entrada de novos feirantes, tornou-se um espaço identificado como "camelódromo". Esse entendimento foi possível a partir da discussão de estudos sobre o tema da identidade nas organizações, com ênfase na questão do espaço e da desterritorialização, o que embasou a análise do percurso semântico da transformação de identidade e de seus subconjuntos da formação de identidade e da clivagem identitária.

\section{Uma revisão sobre o tema da identidade nas organizações}

Os estudos sobre o tema identidade derivam, em grande parte, da psicologia social e da psicanálise, sendo influenciados por diversas correntes de pensamento como, por exemplo, a teoria de identificação social (TIS). Freqüentemente, eles são abordados em diferentes níveis de análise, desde o individual até o coletivo, enfocando essencialmente o indivíduo e o processo socialmente construído por meio do qual ele se relaciona com os outros (MACHADO; KOPITTKE, 2002). Nesse processo, as influências do contexto e do meio cultural exercem um papel relevante na construção da identidade (BORZEIX; LINHART, 1996; NKOMO; COX JUNIOR, 1996; VASCONCELOS; VASCONCELOS, 2000).

Apesar da influência de várias áreas de conhecimento no entendimento da diversidade de identidades, há ainda a falta de um conceito específico sobre diversidade. Para Nkomo e Cox Júnior (1996), o único "consenso" se dá entre acadêmicos e, de maneira parcial, é o de que a diversidade se refere à questão de identidades, tendo como base a filiação em grupos sociais, e também a forma que as diferenças de identidades afetam as relações sociais nas organizações. 
As definições de identidade se resumem a duas categorias: a) as restritas, com ênfase em questões como raça, etnia e gênero; e b) as amplas, onde se incluem fatores como história, formação educacional, estilo de vida e origem demográfica ou qualquer situação onde os atores não são semelhantes em relação a algum ponto (NKOMO; COX JUNIOR, 1996). Observa-se que as restritas tendem a enfocar apenas um aspecto da identidade, enquanto as amplas consideram todas as diferenças existentes entre as pessoas, mostrando que todas são diferentes em algo, o que sugere a dificuldade de se pensar em uma identidade coletiva.

Nogueira (2000) considera que a organização tem sido o locus preferido de referência para análise social, uma vez que compreende as dimensões simbólica e material-estrutural, as quais se encontram atravessadas por relações de poder que fornecem à organização uma noção de ordem. Freitas (1999) também observa a centralidade das organizações na dinâmica da sociedade contemporânea. A autora evidencia que elas servem de modelos às outras instituições da sociedade, uma vez que estas passariam a se orientar pela lógica e racionalidade do trabalho, o que conseqüentemente conduziria a uma homogeneização das instituições na sociedade.

Nesse sentido, Vilaça (2003) assevera que o status e o reconhecimento profissional seriam elementos constituintes da identidade do indivíduo, sendo o valor do indivíduo mensurado pela sua "filiação" a uma determinada organização. Dessa forma, as organizações e instituições forneceriam elementos - de identificação - aos indivíduos, possibilitando-lhes a construção não apenas de uma identidade profissional, mas também, e, sobretudo, a construção de uma identidade social. Por outro lado, Machado (2005) afirma a importância de se considerar o sentimento de identificação por parte dos indivíduos em relação a uma organização, pois segundo a autora esse sentimento de "identificação" ou "filiação" seria imprescindível para a construção e existência da identidade de uma organização (ou instituição).

Já para autores como Fiol, Hatch e Golden-Biddle (1998) e Schultz, Hatch e Larsen (2000), a identidade deve sempre ser definida em relação a um sistema de significações, valores, ideologias, enfim, em relação a uma ou várias culturas. Assim, a identidade de uma organização sempre é afetada pelas significações culturais que perpassam as empresas, estando intrinsecamente relacionada à diversidade de grupos e de atores sociais participantes daquelas, pois estes seriam responsáveis pela elaboração de diferentes culturas e identidades na organização.

Corroborando esse argumento, Borzeix e Linhart (1996) colocam que a identidade nunca seria única, mas se transformaria de acordo com o contexto e a história dos atores organizacionais e da própria organização. Desse modo, essas autoras enfatizam a questão da(s) identidade(s) como um processo de construção social, que se desenrola ao longo de um determinado período, que é mediado pelos discursos dos atores organizacionais, e que, dessa forma, opõe-se à visão de identidade como um atributo da organização.

Autores como Nkomo e Cox Junior (1996) endossam esse processo de construção social de identidades na organização, ao afirmarem que elas se constituem a partir de uma dimensão simbólico-cultural que é historicamente construída e que, por isso mesmo, está sujeita a contradições e ambigüidades no decorrer da vida de um grupo social, de uma organização ou instituição. Com isso, as identidades de uma dada organização poderiam variar ao longo de sua existência, conforme a (re)construção simbólica baseada nas representações e nos valores socialmente compartilhados pelos diversos atores organizacionais. Nesse sentido, Carrieri (2001) ressalta que tanto o contexto externo da organização quanto o interno devem ser estudados para que se possa compreender as transformações ocorridas nos valores, normas e nos processos de interação dos indivíduos, grupos, da organização e destes entre si. Esses elementos serviriam de base para se chegar a compreensão de transformações nas identidades.

Para autores como Chanlat (1992), Pratt e Foreman (2000), a identidade coletiva emerge a partir das relações entre os indivíduos, quando da formação dos grupos sociais. Nesses grupos, cada indivíduo seria responsável por representar um determinado papel, uma função social dentro do grupo, o que implicaria a noção de pertencimento coletivo, um sentimento de filiação. Para Hatch e Schultz (2000) e também Machado (2005), a identidade organizacional é coletiva no sentido de ser uma representação compartilhada. Assim, a construção de uma dada identidade estaria baseada na construção de representações compartilhadas pelos atores sociais, que exerceriam determinados papéis ou funções, dentro de um dado grupo ou organização. 
Assim, a existência de diversos mundos sociais representaria a existência de diversos universos de significação, nos quais imperariam diferentes ordens de grandeza e hierarquia de valores, símbolos, normas de comportamento, regras e aspectos sociais válidos, que forneceriam um determinado valor social ao indivíduo. Esse indivíduo, por sua vez, deveria se portar de uma maneira ou desempenhar determinados papéis sociais dentro do grupo. De um modo geral existiriam seis universos de significação - o mercantil, o doméstico, o cívico, o industrial, o da opinião e o da inspiração - que se comunicariam entre si, permitindo a existência de diferentes tipos de capital e de modos de legitimação social (VASCONCELOS; VASCONCELOS, 2003).

Nogueira (2000, p.93), considerando essa questão dos papéis e da legitimação social, argumenta que "as pessoas configuram e estruturam a sua realidade como num processo de representação". Essa idéia enfatiza o papel de ator social, no qual o indivíduo contribui conscientemente para a criação de seu mundo, existindo assim, uma vinculação entre estruturas e processos da organização, de idéias e crenças. E por sua vez, tal vinculação seria determinada pela combinação de estruturas prescritivas - já dadas -, com interações emergentes, nas quais os atores organizacionais reafirmariam ou subverteriam os usos e significados daquelas.

Assim, para esta pesquisa, o conceito de identidade é o mesmo adotado por Nogueira (2000, p.97), que corresponde a uma determinada visão de mundo "[...] resultante de representação compartilhada dos membros de uma organização e daqueles com quem ela interage". Esse conceito, ao se basear na forma como os atores sociais (membros internos e externos de uma organização) percebem a noção de identidade corrobora, de certa forma, a visão de que a identidade organizacional pode ser percebida também pela finalidade da organização, ou seja, o propósito ou o objetivo comum que reuniria todos os membros da organização e a missão, ou como ela seria percebida pelo público.

A identidade seria o resultado de um processo de construção social, cujos significados seriam socialmente compartilhados pelos atores sociais e organizacionais (MACHADO, 2005), podendo ser apreendido, considerando-se três critérios propostos por Albert e Whetten (1985): a) centralidade, referente aos traços reveladores da essência da organização; b) distintividade, aspectos que diferem uma organização em relação àquelas que lhe são semelhantes; e c) continuidade temporal, ou seja, as características que tendem a se manter ao longo do tempo.

Assim, o processo de construção das identidades sociais e organizacionais estaria baseado num processo dialético de interpretação, reconhecimento e legitimação referenciados em outros agentes que, no caso, seriam indivíduos, grupos, organizações ou grupos de organizações que estariam dispersos no macroambiente social e institucional e num determinado espaço físico e simbólico. Desse modo, a partir da dinâmica de atuação dos diferentes atores sociais e organizacionais em um dado contexto é que se poderia apreender o processo de construção das identidades a partir de suas transformações ao longo de um curso temporal e espacial.

\section{0 espaço e a desterritorialização}

Ferretti (2000, p.53) afirma que o estudo das feiras teria por finalidade conhecê-las através de suas estruturas e funções econômicas, sociais e simbólicas, tais como cultura e identidade, desvendando "[...] os componentes ideológicos que estão por trás das relações que as pessoas estabelecem a partir do ato de vender e comprar". Nesse sentido, as feiras possuiriam um caráter transcendente às suas simples manifestações e expressões comerciais, remetendo a um significado oculto, mais profundo, que estaria no âmago das relações estabelecidas pelos indivíduos participantes. Souza (2000) ratifica essa visão, ao asseverar que as feiras são instituições cujas representações socioculturais estão contextualizadas em uma determinada noção de espaço (físico e simbólico) e de tempo que, por sua vez, conferiria às mesmas uma identidade cultural.

Desse modo, por meio de sua identificação em relação aos demais espaços de socialização - seja por qualquer uma de suas funções -, as feiras adquiririam uma função simbólica de acordo com o contexto no qual elas estariam inseridas. Além disso, elas poderiam sofrer transformações ao longo do tempo - por intervenção, descaracterização e/ou atribuição de novos significados pelos seus participantes e pela a sociedade em geral -, o que permitiria uma transformação e (re)configuração identitária de tais instituições (SOUZA, 2000). 
Para Certeau (1990), o uso cotidiano dos espaços físicos e simbólicos pertencentes a cada grupo social seria um exemplo claro das transformações nas significações culturais e identitárias existentes na sociedade, e em qualquer organização, pois cada grupo transformaria em "seu" o espaço social, através de bricolagens para o seu uso cotidiano. No dia-a-dia das instituições, poder-se-ia observar essa tradução, principalmente, pelos usos simbólicos internamente aos grupos. Esses usos se manifestariam nas diferentes formas de disposição e de relação dos indivíduos e grupos com um determinado espaço.

As mudanças nas significações culturais buscariam promover duas estratégias: a primeira, provocar um desenraizamento real e simbólico dos espaços; a segunda, tentar fazer com que a organização, por sua vez, aparecesse como um novo "espaço particular da experiência humana", um "lugar privilegiado de enraizamento" (CHANLAT, 1992, p.30-31). É nesse lugar que novas significações para as carreiras e conquistas pessoais dos atores poderiam ser construídas (RODRIGUES, 1997), conferindo sentido às experiências pessoais, profissionais e sociais dos indivíduos participantes de tais organizações.

Para Harvey (1992), a apropriação do espaço traduz a maneira pela qual ele é ocupado por objetos, atividades, indivíduos, grupos, organizações etc. No caso particular de uma organização, o domínio sobre o território ${ }^{1}$ reflete como os grupos dominantes se apropriam da produção dos espaços físicos e simbólicos, a fim de poderem exercer um maior grau de controle sobre os indivíduos. O território pode ser visto, então, não somente pela perspectiva do domínio físico, mas de uma apropriação que incorpora, segundo esse autor, a dimensão simbólica e, pode-se mesmo dizer, identitária, e afetiva.

O território preenche o espaço com conteúdos particulares, relacionados a construções históricas entre pessoas, organizações e o Estado. A territorialidade, segundo Correa (1996), refere-se ao conjunto de práticas e suas expressões materiais e simbólicas que garantiriam uma apropriação e permanência em um dado espaço por determinados grupos sociais e organizacionais. Em um sentido contrário, o movimento denominado desterritorialização viria para esvaziar o território (e os espaços ocupados) de seu conteúdo relacional e particular que promoveria uma identificação entre os indivíduos e as organizações. Assim, a desterritorialização pode ser vista como: a) uma estratégia dos grupos dominantes para conter, restringir e até excluir pessoas, isto é, como um movimento de (re)apropriação do território, dos espaços físicos e simbólicos (GUATTARI, 1986; PAGÉS; GAULEJAC; DESCENDRE, 1987); b) um movimento de rompimento da memória (história) organizacional que, para ser compreendida, necessita de uma referência territorial, pois se atualizaria sempre no espaço da organização (ORTIZ, 1994); e c) um processo de "deformação" da relação do indivíduo e grupos com a organização (PAGÉS; GAULEJAC; DESCENDRE, 1987). Desse modo, a noção de espaço (físico e simbólico) estaria intimamente ligada à questão da identidade, na medida em que serviria de base, pela sua dimensão física, à construção de racionalizações sobre formas de agir e pensar entre determinadas pessoas de um grupo social, constituindo-se assim, no plano simbólico, como referência para possíveis identificações entre o grupo e o espaço.

\section{Caminhos percorridos}

Autores como Rodrigues, Carrieri e Luz (2003) defendem a idéia de que a abordagem semiótica dos discursos nas organizações possui a capacidade de descrever a inter-relação de fatos observáveis e o conjunto de regras de qualquer sistema de significados coletivamente compartilhados. Essa abordagem enfatizaria a articulação contextual como fonte de sentido, por meio de forças mantenedoras (elementos de coesão), e inovadoras (elementos de rompimento e recriação) para os atores organizacionais (NOGUEIRA, 2000).

Corroborando essa perspectiva, este estudo utilizou a análise do discurso (AD) para investigar os textos escritos e as entrevistas coletadas. Como paradigma teórico e metodológico de análise, a $\mathrm{AD}$ possibilita a apreensão das formas de produção do discurso e das estruturas materiais e sociais que as elaboram. Pode-se considerá-la uma técnica potencialmente útil nas análises de processos ou fenômenos sociais. Isso se deve ao fato da $\mathrm{AD}$ evidenciar que o (indivíduo) enunciador, enquanto (re)produtor de discursos, está ligado de modo interdependente ao seu contexto social, histórico e cultural, ou seja, ao seu locus de produção do discurso (MAINGUENEAU, 1998). Dessa forma, a AD permite a compreensão em profundidade da realidade social, refletida na formação discursiva, por meio da apreensão de discursos dos atores sociais. 
Para Rowlinson e Procter (1999), o uso de documentos históricos é uma fonte de informação imprescindível aos estudos que buscam compreender a interface das culturas e também das identidades com a história da organização ou instituição. Para esses autores, os documentos escritos retratam mais fielmente uma conjuntura histórica, já que as respostas às entrevistas - quando se referem a um passado já vivido pelos atores - advêm de reflexões construídas a posteriori. Mumby e Clair (1997) também ressaltam a importância de pesquisas sobre as histórias organizacionais (e institucionais), como fonte de conhecimento que ganham, cada vez mais, ênfase nos estudos organizacionais, o que novamente justifica a sua adoção neste estudo. Assim, para este estudo, os discursos escritos e as entrevistas (discursos falados) elaborados nas narrativas revelariam a articulação entre a transformação identitária e a ocupação e desocupação dos espaços, enfim, os movimentos de desterritorialização e reterritorialização.

Para concretizar a abordagem empírica desta pesquisa, procedeu-se a um estudo de caso da Feira de Arte, Artesanato e Produtores de Variedades de Belo Horizonte, por meio de duas categorias básicas de análise existentes na AD: a) o conjunto de temas e figuras ${ }^{2}$ que constituem o percurso semântico de um dado discurso; ${ }^{4}$ e b) o uso de estratégias discursivas de persuasão, conforme a instrução de Faria (2001). Cabe ressaltar que ambas categorias estão articuladas nos níveis inter e intradiscursivo ${ }^{5}$ dos discursos (con)formados na história da Feira.

Neste estudo foram analisados 98 documentos escritos, a partir da produção textual de diversas fontes, como artigos de jornais de grande circulação em Belo Horizonte, textos de diferentes associações de artesãos dentro da Feira, do "jornalzinho" de circulação interna da Feira e documentos da própria Prefeitura de Belo Horizonte, como ofícios, cartas etc. Também foram analisados ofícios da Assembléia Legislativa de Minas Gerais, entre outros. Deve-se destacar, ainda, que também foram realizadas duas entrevistas semi-estruturadas: uma com o secretário de Assistência Social da Prefeitura de Belo Horizonte e outra com a gerente regional de Feiras. Tais entrevistas se justificaram devido à escassez de dados oficiais sobre a Feira e pela necessidade de obter uma visão da Prefeitura Municipal de Belo Horizonte sobre seu papel institucional na gestão, a fim de relacionar esses dados àqueles obtidos nas fontes documentais.

Segundo Faria e Linhares (1993), um procedimento bastante usado na compreensão dos discursos e de seus percursos semânticos são as estratégias de persuasão. Faria e Linhares (1993) relatam a existência de quatro principais estratégias de persuasão: 1 . a construção das personagens no discurso e sua relação com as personagens efetivamente existentes; 2 . a seleção lexical, isto é, a escolha do vocabulário usado nos discursos; 3. as relações entre os conteúdos explícitos e os implícitos, que possibilitam criar um efeito ideológico de sentido, baseado nos implícitos pressupostos, nas partes não ditas porém integrantes do enunciado, e nos subentendidos, inferências retiradas do contexto pelo interlocutor com a ajuda de um raciocínio; e 4. o silêncio sobre determinados temas, ou seja, aquilo que não é dito.

O estudo de tais estratégias permitiria compreender como os discursos são "aprendidos no decorrer da vida dos atores sociais, no decorrer de suas 'vidas' organizacionais" (FARIA; LINHARES, 1993, p.38). Portanto, justifica-se o uso da $\mathrm{AD}$ neste estudo, visto que ela possibilitaria a interpretação não apenas do que é dito e explicitado, mas sobretudo, a apreensão da ideologia que está por trás dos discursos, entendendo o que não necessariamente está explícito. Assim, revelar-se-ia o que está de alguma forma manifestado no discurso dos atores sociais e organizacionais, contribuindo para a compreensão do conjunto de transformações identitárias ocorridas na "Feira Hippie" ao longo de sua história.

\section{Revelando um pouco da história da Feira de Arte Artesanato e Produtores de Variedades ("Feira Hippie") de Belo Horizonte}

A Feira de Arte e Artesanato de Belo Horizonte, hoje denominada Feira de Arte, Artesanato e Produtores de Variedades da Avenida Afonso Pena, surgiu em 1969 na praça da Liberdade, quando um grupo de intelectuais inspirados nas experiências de outros países, decidiu criar um espaço artístico e cultural na cidade, com a finalidade de "levar a arte ao povo" e torná-la acessível a todas as camadas da população (ALBANO et al, 1984). Para Guerra (2002), as pressões políticas e sociais pelas quais o país, e Belo Horizonte, passavam nos anos 1960 e 1970 eram fruto de um contexto histórico de manifestação e contestação à repressão da Ditadura. Isso faz com que " [...] logo no início a Feira passa a 'ser identificada popularmente como FEIRA HIPPIE', denun- 
ciando 'simbolicamente' uma postura de contestação típica do Movimento HIPPIE americano." (CALDEIRA, 1998, p.115).

Nos anos 1980 a "Feira Hippie" passou por constantes mudanças, seja em suas características físicas - como, por exemplo, o número de participantes -, seja em relação as suas características intrínsecas ou subjetivas quanto à qualidade dos produtos e a percepção do público sobre a imagem da Feira perante a sociedade. Assim, devido a uma série de mudanças ocorridas na Feira - em especial o aumento desordenado do número de participantes, e sob o pretexto de que a praça da Liberdade não comportava mais essa enorme quantidade de feirantes e de público -, em 1991, a "Feira Hippie" foi transferida para a avenida Afonso Pena, outro ponto central da cidade de Belo Horizonte, porém, com maior amplitude para abrigar os feirantes e consumidores.

Atualmente, estima-se que a Feira gere, aproximadamente, 15.000 empregos diretos e indiretos, entre os montadores de barracas, carregadores, pessoal de limpeza e fiscalização, além dos 3.000 artesãos. A "Feira Hippie" também é tida como a maior atração turística de Belo Horizonte, sendo considerada "um verdadeiro shopping a céu aberto" que atrai um contingente maior do que a população de muitos municípios mineiros - cerca de 80 mil pessoas - e movimenta uma parcela "significativa" do PIB de Belo Horizonte, cerca de R\$800 mil semanalmente (BELOTUR, 2004, p.1). Considerando que ao longo de sua história a "Feira Hippie" passou por diversas mudanças, derivadas em grande parte de mudanças realizadas nas e pelas organizações familiares que a compõem e que, ao mesmo tempo, influenciaram de forma direta os negócios de tais organizações, defende-se aqui que a "Feira Hippie" pode ser melhor compreendida a partir de uma visão temporal, onde percebe-se a existência de momentos distintos com características específicas que os marcaram.

Cronologicamente, ela pode ser dividida em quatro ${ }^{6}$ períodos, a fim de facilitar sua compreensão: a primeira fase se estende de 1969 até 1983, compreendendo o momento de criação da Feira, a sua aceitação pelo público e, conseqüentemente, o seu crescimento; a segunda fase, que corresponde ao período de 1984 a 1988, onde houve um nítido desvirtuamento das características originais da Feira; a terceira fase, que vai de 1989 a 1991, quando houve a mudança do local da Feira; e a quarta fase, de 1992 até os dias atuais.

Essa divisão não é estática, coexistindo assim diferentes características nos momentos de transição. No entanto, essa visão temporal serviu de referência contextual para se analisar os documentos selecionados. Além disso, a partir dessa divisão cronológica, que evidencia as características contextuais de cada período, foi possível identificar de modo mais acurado as transformações identitárias ocorridas e sua relação com o contexto social, histórico e cultural no qual ela estava inserida (NKOMO; COX JÚNIOR, 1996).

\section{Transformando a identidade: a análise do percurso semântico}

Por meio da identificação das estratégias de persuasão empregadas pelos atores sociais e organizacionais da "Feira Hippie" (extraídas do conjunto de documentos coletados relativos à história da Feira), buscou-se relacionar o percurso semântico circunscrito ao âmbito intradiscursivo às oposições constitutivas do interdiscurso para, desse modo, (re)construir o percurso semântico aqui analisado. É importante ressaltar que as estratégias de persuasão utilizadas nas fontes textuais foram elaboradas por diferentes atores socais e organizacionais, tais como a Prefeitura de Belo Horizonte, a imprensa belo-horizontina, os próprios feirantes, os freqüentadores, os "turistas" etc., para se referir à (trans)formação de identidade da Feira ao longo do tempo.

Assim, na análise dos 36 anos de história da Feira foi possível evidenciar a existência de um percurso semântico denominado transformação de identidade. Este, por sua vez, estrutura-se em dois subconjuntos que se subdividem em temas para detalhar mais os níveis de análise. O primeiro subconjunto, da formação de identidade, constitui-se a partir dos seguintes temas: a) influência hippie, b) a finalidade da Feira; e c) a influência do espaço. Já o segundo subconjunto, da clivagem identitária, baseia-se nos temas: a) influência política e o supercrescimento da Feira; b) a mudança de função da Feira, de espaço cultural para espaço comercial; e c) a mudança espacial, da praça da Liberdade para a avenida Afonso Pena. 


\section{O subconjunto da formação de identidade}

O primeiro subconjunto, da formação de identidade, subdividiu-se em três temas: a) a influência hippie; b) a finalidade da Feira, com o tema subjacente da função socioeconômica; e c) a influência do espaço. Tais temas sintetizaram, de modo geral, as principais características da formação de identidade da Feira em sua fase inicial.

O primeiro tema, influência hippie, foi narrado pelos enunciadores em diferentes sentidos. No primeiro sentido, observa-se uma aproximação dessa influência com o processo de criação da Feira, explicitado pela mobilização da personagem discursiva "artistas", que seriam adeptas desse estilo de vida alternativo e teria a função de levar a arte e cultura ao povo. Esse é um implícito, subentendido, a que se chega a partir da seleção lexical "a mostra", vocábulo notadamente erudito e usado em ambientes culturais, referindo-se a uma exposição de arte.

O uso dessa expressão "a mostra" para se referir à exposição de trabalhos artesanais em praça pública expõe, por meio da relação de conteúdos implícita de modo subentendido, a contradição semântica na qual a personagem "povo" - classificada como desprovida de muita cultura erudita ou conhecimento artístico - estaria realizando uma mostra de trabalhos artísticos. O entendimento de que a personagem discursiva "povo" não teria competência para realizar tal fato é outro implícito, de modo subentendido, a que se chega pelo fato de se atribuir o nome de "Feira Hippie" a uma mostra de trabalhos artísticos. Desse modo, denota-se o não entendimento do significado "cultural" e "artístico" daqueles trabalhos, confundindo-os com "artigos" quaisquer, donde se infere que seriam de menor relevância em relação aos anteriores. Ainda no trecho, surge o vocábulo "compravase" que sugere, por meio de um implícito pressuposto, o caráter comercial da atividade, além de seu caráter cultural, como fica evidenciado, de modo implícito pressuposto, pela seleção lexical "a mostra". O trecho ainda deixa silenciado quem seriam os compradores, através da indeterminação da regência do verbo comprar, conforme pode ser observado no fragmento 01.

(01) Devido à onda "hippie", que marcou a época e o estilo de vida dos artistas, a mostra foi chamada pelo povo de "Feira hippie", onde comprava-se bons artigos a preços acessiveis [...]. (ARANHA, 1994)

Nesse trecho, além da personagem explícita "artistas", aparece implicitamente, de modo subentendido e metafórico - por meio da expressão "onda "hippie"" -, a personagem discursiva "participantes da feira que não eram artistas", pertencentes a esse grande contingente de pessoas que é designado pela escolha lexical do vocábulo popular "onda". Assim, a figura do "hippie" estabelece uma relação contextual, por meio do aposto explicativo "que marcou a época e o estilo de vida dos artistas", utilizado para explicitar a relação inicial de pelo menos parte dos artistas com o movimento de contracultura e com a Feira, sendo, portanto, identificada com uma metonímia desta última.

Reforçando o papel da influência hippie no fragmento 02 , o enunciador utiliza o recurso polifônico, marcado pelo uso de aspas, indicando a fala de outra pessoa, para veicular, em tom de concordância, as idéias difundidas pela personagem "Mari'Stella Tristão". Idéias essas que se referem aos temas "liberdade", "questionamento", notadamente marcados pelo movimento hippie. No trecho, a figura discursiva "Woodstock" é simbolicamente colocada para situar o leitor sobre as características intrínsecas ao surgimento da Feira, traçando um paralelo com o movimento contracultural ocorrido nos EUA. Desse modo, a seleção lexical "Woodstock mineira" funciona como uma metáfora que leva ao implícito subentendido do significado de contestação, algo de diferente que a Feira possuía e não possui mais, pois a conjugação do verbo "haver" - no pretérito imperfeito do indicativo - leva ao implícito pressuposto de que a Feira não mais possui tal característica.

(02) havia "todo aquele clima de uma Woodstock mineira" [...]. (Mari'Stella Tristão) (ACERVO BELOTUR, 2004)

Em sentido oposto, alguns trechos ressaltaram a exclusão da influência hippie no processo de criação da Feira. No fragmento 03, o enunciador mobiliza a mesma personagem "Mari'Stella Tristão", qualificando-a por meio do aposto explicativo "crítica de arte", a fim de produzir um efeito de credibilidade sobre o enunciatário. A se- 
leção lexical "alguns hippies" gera o implícito pressuposto de que esses atores sociais eram em pequeno número, acentuando-se, ainda, o efeito ideológico de sentido (FIORIN, 2003) produzido pela seleção lexical "alguns" acrescida do destaque tipográfico em negrito na personagem "hippies", que gera pelo menos dois implícitos: a) o subentendido de que esse elemento mantém relação de oposição à personagem "Mari' Stella Tristão", qualificada como crítica de arte; b) o subentendido de que essa relação de oposição inferioriza a personagem "hippies", cujo predicativo está silenciado no texto.

(03) Mari'Stella Tristão, crítica de arte, afirma que na época [de criação da Feira] havia alguns hippies expondo seus trabalhos, mas não uma feira organizada. (EDIÇÃO DO BRASIL, 1987, negrito do autor)

Contudo, o silenciado no texto nos leva a uma relação de conteúdos explícitos e implícitos, pode-se dizer que há dois implícitos pressupostos, respectivamente: a) a idéia de que a Feira organizada surgiu depois dos hippies; b) de que a exposição dos trabalhos dos hippies era desorganizada; bem como os implícitos subentendidos de que a desorganização vinha do próprio elemento hippie e seu estilo de vida, e de que a noção de Feira organizada tem um valor maior, e melhor, sendo mais importante que o modo que existia antes.

Por fim, a versão oficial, isto é, a versão difundida e registrada pela Prefeitura Municipal de Belo Horizonte no primeiro Regulamento da Feira de Arte e Artesanato, elaborado pela Superintendência de Turismo da Prefeitura de Belo Horizonte em 20 de agosto de 1972, no qual evidencia-se a mobilização das seguintes personagens: os "artistas e críticos de arte", que compuseram um grupo e idealizaram a Feira, e o "prefeito", que acatou a "sugestão" deles e resolveu instituí-la.

A partir disso, temos as figuras da Feira, do grupo e do prefeito, que representam personagens privilegiados no texto, notadamente, marcados pelos elementos deslocados no texto e produzindo efeitos ideológicos na apreensão do sentido. A "FEIRA" é colocada em maiúsculas indicando, assim, o seu caráter de entidade instituída (e legitimada pelo poder público). O "GRUPO" ressalta a característica de uma idealização coletiva. E o "Prefeito Municipal", a quem é atribuído o status e poder de legitimar e instituir a Feira - trecho 04. Ainda sobre a criação da Feira e seu regulamento, o fragmento 05 deixa de modo explícito a centralidade de suas funções culturais que, por sua vez, implicariam desdobramentos socioeconômicos. Nesse sentido, observa-se, por meio de um implícito pressuposto, que a função cultural seria precedente à, e mais importante do que a comercial.

(04) A FEIRA DE ARTE E ARTESANATO DE BELO HORIZONTE foi idealizada por um GRUPO de artistas e críticos de arte de Belo Horizonte, e encaminhada a sugestão ao Prefeito Municipal no ano de 1969. (BELO HORIZONTE, 1972)

(05) [...] Instituída com a finalidade de promover, divulgar e popularizar as artes plásticas e o verdadeiro artesanato, a FEIRA se destina a dar oportunidade a artistas e artesãos [...] para vender, em logradouro público aberto, o produto de seu trabalho, [...]. (BELO HORIZONTE, 1972, negrito do autor)

O trecho 05 evidencia o tema finalidade da Feira de Arte e Artesanato, ou seja, o que se pretendia atingir com a sua criação, sendo tal característica notadamente cultural, conforme o explícito destacado em negrito. As funções culturais estão explícitas nas expressões metonímicas "artes plásticas" e "verdadeiro artesanato", que levam ao implícito, pressuposto, de que a Feira deveria expor produtos relacionados à cultura. É possível extrair, pelo menos, mais dois implícitos relacionados à expressão "verdadeiro artesanato": um, pressuposto, de que existiria, em contraposição àquele tipo, o "artesanato ilegítimo"; e outro, subentendido, de que o verdadeiro artesanato estaria ligado à cultura, sendo, portanto, melhor que o "artesanato ilegítimo" - que se subentende ser afastado da cultura.

Como tema subjacente à finalidade da Feira, tem-se o tema da função socioeconômica que funcionaria como meio de divulgação das "artes plásticas" e do "verdadeiro artesanato". Essa função socioeconômica é decorrente de pelo menos dois implícitos, pressupostos: a) o fato de que o meio ou a forma escolhida para a divulgação das artes e artesanato ter sido a comercialização; e b) o de que é necessário existir alguém que produza as 
artes e artesanato para que ele seja divulgado por meio da comercialização. Estes remeteriam às personagens discursivas "artistas" e "artesãos".

Por um lado, haveria as funções sociais, veiculadas por meio das expressões "dar oportunidade" e "em logradouro público", funções essas que implicam o implícito subentendido que a Feira deveria ter um caráter coletivo, voltada ao público de um modo geral, seja por meio da participação direta, como feirantes, ou indireta, como freqüentadores. É interessante ressaltar que a escolha lexical "dar oportunidade" remete ao implícito pressuposto de que alguém está propiciando algo em favor de terceiros, chegando ao implícito subentendido que a personagem discursiva implícita no trecho - "Prefeitura de Belo Horizonte" - estaria oferecendo uma oportunidade às personagens explícitas "artistas e artesãos". Esta expressão funciona ainda como um eufemismo para o termo emprego, denotando o caráter social da Feira; ou seja, a Feira seria vista como um tipo de lugar onde os seus participantes poderiam ter alguma espécie de renda e, logo, extraírem dali meios para o seu sustento.

Por outro lado, haveria também funções econômicas que podem ser apreendidas pelas seleções lexicais: 1) "vender", onde o verbo pressupõe o envolvimento de, pelo menos, dois agentes em uma relação comercial, ratificada pelo aposto especificativo "em logradouro público aberto", que determina o lugar de materialização dessa relação; e 2) "produto", que implica o implícito pressuposto da fabricação desse produto e, portanto, das relações econômicas envolvidas nesse processo. O outro aposto especificativo, "o produto de seu trabalho", pressupõe a exclusão da possibilidade de venda de produtos cuja origem tenha se dado por força de trabalho de terceiros, ou seja, por trabalhos que não se caracterizariam como produção individual artística e/ou artesanal.

Ainda nesse trecho, é possível observar o uso do vocábulo "instituída", que se refere ao caráter de legitimidade da figura "FEIRA" perante a personagem mobilizada Prefeitura de Belo Horizonte, que seria a responsável pela instituição daquela. Observa-se, também, o uso da expressão "logradouro público aberto", que remete a um tipo de linguagem técnica, rebuscada, para se referir ao termo "rua". Essa escolha lexical, implicitamente, de modo subentendido, pode ser vista como uma forma de a personagem implícita, no trecho 05, "Prefeitura", demonstrar seu domínio do saber e, portanto, legitimar seu poder perante a sociedade e a instituição de seus atos - como é o caso da criação da "FEIRA". Por fim, o trecho 05 deixa como silenciado a definição do que é o "verdadeiro artesanato".

Dentro do percurso semântico da transformação de identidade, em seu subconjunto da formação de identidade, surgiu um terceiro tema da influência do espaço, que foi caracterizado pela vinculação da "Feira Hippie" ao espaço físico da praça da Liberdade, em Belo Horizonte (MG), onde se deu o seu surgimento.

Nesse tema, o espaço é associado, simbolicamente, à tradicionalidade da praça da Liberdade, e fisicamente (ou geograficamente) à sua localização estratégica, em termos de centralidade geográfica e social, uma vez que a praça era tida como um ponto de encontro da população, conforme o trecho 06. Assim, o tema da influência do espaço na constituição da formação de identidade da "Feira Hippie" e de seus comerciantes remete, simultaneamente, a um valor de uso, denotado pela adequabilidade e praticidade, e a um valor simbólico, manifesto pela sua tradicionalidade e significado atribuído pela sociedade.

Nesse tema, no fragmento 06, aparece a personagem mobilizada "idealizadores", que por meio de um implícito subentendido pode ser associada às personagens explícitas no trecho 04. Os "idealizadores" seriam os responsáveis pela escolha da praça da Liberdade como local para sediar a Feira em virtude de ser um "local adequado e prático". Vale ressaltar que o uso de aspas dentro do discurso do enunciador cria um efeito ideológico de transferência de responsabilidade, ao usar a polifonia ${ }^{7}$ como recurso lingüístico.

(06) [...] a Praça da Liberdade foi escolhida um "local adequado e prático", na opinião de seus idealizadores. (EDIÇÃO DO BRASIL, 1987)

Já o fragmento 07 apresenta justificativa oficial da prefeitura, através da narração da personagem discursiva "Norman Kutova", secretário de Cultura e Turismo da época, para quem a "tradição" da praça faria dela o melhor lugar para se instalar a Feira. Tal característica alude ao implícito pressuposto de que a praça da Liberdade já era um espaço valorizado antes da criação da Feira. Valorização essa denotada pela sua escolha para ser a sede administrativa da capital do Estado, quando da construção de Belo Horizonte, devido ao fato de ser o pon- 
to altimetricamente mais elevado da cidade, relacionando-se assim o espaço físico ao simbólico, o da significação do poder do governo, materializado nas secretarias e órgãos públicos (ALBANO et al, 1984). Além do tema da tradição, a personagem se refere ao espaço, metaforicamente, por meio das expressões "espaço cultural", "opção de lazer" e "atração turística", no sentido de legitimar o uso de seu espaço para a realização da Feira, aproximando-o do público.

(07) Norman Kutova [...] afirmou que a Praça da Liberdade, por sua tradição, é o melhor espaço cultural de Belo Horizonte; que se deve aproveitá-la como uma opção de lazer e, por fim, como uma atração turística. (BELO HORIZONTE, 1979)

O fragmento 08 também procura legitimar o uso do espaço da praça da Liberdade, através de sua qualificação como espaço ímpar, ideal para a realização do evento. As escolhas lexicais das expressões "agradável", "bem arborizada", "cercada por um belo conjunto arquitetônico" e "invulgar tradição de frequiência do público" deixam explícito o porquê da escolha desse local, "ao contrário das demais praças da cidade". Assim, tanto os elementos naturais, como os culturais e os sociais, marcados pelas expressões "conjunto arquitetônico" e "frequiência do público", evidenciam a característica espacial física e simbólica da praça sobre a população. Apesar da citação de várias qualidades, o enunciador não atribui a nenhuma personagem discursiva a responsabilidade pela utilização desses predicados.

(08) O local escolhido, evidentemente, não poderia ser outro senão a Praça da Liberdade. Agradável e bem arborizada, cercada por um belo conjunto arquitetônico e uma invulgar tradição de freqüiencia do público, ao contrário das demais praças da cidade. (MOURA, 1988)

Na passagem 09, o tema influência do espaço aparece sob a metáfora da localização estratégica e se relaciona, implicitamente e de modo subentendido, à "invulgar tradição de frequiência do público" manifestada no fragmento 08 , que faz da praça um "ponto estratégico para expor idéias e fazer protestos". A seleção lexical "estratégico" remete à questão do melhor ponto ou do ponto vital para esses tipos de manifestações. Por meio da oração "A manifestação de arte e saber ganhou ares de comércio", chega-se ao implícito, pressuposto, da questão da transformação de identidade. Os explícitos "ganhou ares de comércio" e "precisou ser transferida" levam aos seguintes implícitos, pressupostos: a) o de que, anteriormente, ela não tinha finalidade comercial; b) de que essas mudanças, que ocorreram dentro do mesmo espaço físico (praça da Liberdade), influenciaram na mudança do espaço de realização da Feira; e também ao implícito subentendido c) de que no novo local "que abriga milhares de artesãos", a finalidade principal da Feira é a socioeconômica, metaforizada pela seleção lexical "abriga", no sentido de dar proteção (social) e prover condições de existência.

Assim, a mudança espacial da "Feira Hippie" da praça da Liberdade para a avenida Afonso Pena (outro ponto central da cidade de Belo Horizonte) implica o implícito subentendido de que houve uma ruptura em termos de sua identidade, explicitada pelo aposto explicativo "que abriga milhares de artesãos", onde o termo "milhares" estabelece uma relação de conteúdo contrária àquela do caráter inicial da Feira de "movimento cultural", onde os termos "alguns hippies", "um grupo de artistas e críticos" (respectivamente dos fragmentos 03 e 04) explicitam o seu caráter restrito.

O termo "milhares" ainda faz referência intertextual ao tema subjacente "crescimento desordenado", presente no tema influência política do subconjunto da clivagem identitária.

(09) [...] o movimento cultural que começou em 1969 com encontros semanais de artistas e intelectuais na Praça da Liberdade, ponto estratégico para expor idéias e fazer protestos. A manifestação de arte e saber ganhou ares de comércio e precisou ser transferida para a [avenida] Afonso Pena, que abriga milhares de artesãos. (ODILLA, 2004)

Assim, as principais características da Feira, especialmente em uma fase inicial, mas que se estendem até o momento de sua mudança espacial, estariam sucintamente representadas anteriormente por meio dos temas da influência hippie, da finalidade da Feira e da influência espacial. Tais temas, por sua vez, estão intrinsecamente relacionados às características que irão conferir a formação de identidade da "Feira Hippie". O tema da influência hippie designa que a Feira foi criada sob a égide de uma determinada ideologia, no caso a do movi- 
mento hippie, que criticava a sociedade de consumo capitalista e propunha um sistema alternativo com outras possibilidades de produção, de consumo e de produtos diferentes daqueles efêmeros apregoados pela sociedade de consumo do sistema capitalista vigente. A influência da ideologia hippie permeou as bases da Feira, inserindo-lhe características que iriam conformar sua base identitária e, dessa forma, conduziria os seus comerciantes e ela própria (como resultado da união desses últimos), a adotar determinados padrões de ação, tomando-se como base esse quadro de referência. Como afirma Carrieri (2001), a identidade serviria para dar aos indivíduos, grupos e organizações padrões de referência ao situarem tais elementos num dado contexto, numa dada posição, possibilitando que aqueles indivíduos tenham uma dada localização social, ou seja, localizem-se e sejam localizados pelos demais.

Adotando os parâmetros de análise propostos por Albert e Whetthen (1985), pode-se considerar a influência hippie como um elemento que propicia uma certa continuidade temporal. Ela confere uma noção de estabilidade, um enraizamento de subjetividades advindas da ideologia do movimento hippie defendida pelos expositores da Feira. Isso, por sua vez, resultará em uma incorporação de tais valores dentro de suas organizações e na própria identidade organizacional da "Feira Hippie" como instituição. Esse acontecimento é justificado, já que tal elemento seria tomado como um valor comum e compartilhado pelos membros do grupo social, reiterando a essência daquelas organizações familiares dos diversos comerciantes que compunham a Feira em sua fase inicial.

Por sua vez, o tema da finalidade da Feira evidencia a essência da organização, ou seja, ele encerra em si mesmo a finalidade para a qual aquela organização, instituída e legitimada pelo poder público - representado pela Prefeitura Municipal de Belo Horizonte - foi criada, que segundo a prefeitura pretendia "[...] promover, divulgar e popularizar as artes plásticas e o verdadeiro artesanato, [...]." (BELO HORIZONTE, 1972, negrito do autor)

Apesar da finalidade cultural da Feira, como foi o explicitado anteriormente, a instituição da mesma, sobretudo pela forma como se deu, levou à agregação de outras finalidades subjacentes àquela. A finalidade da Feira visava estabelecer e manter, em um local específico, o estímulo à produção e exibição de peças artísticas e artesanais, corroborando assim a ideologia da influência hippie. Observa-se que tais produtos trazem consigo a característica de serem exclusivos, não-padronizados e não-repetitivos, opondo-se dessa forma à característica dos produtos industrializados e consumidos em massa.

Contudo, à finalidade inicial (ou principal) foram agregadas outras finalidades, como a social e a econômica que, por sua vez, vão culminar ao longo do tempo no embate em termos de prioridade em relação à finalidade cultural, levando assim, os novos feirantes que foram entrando ao longo do tempo a aderirem apenas à finalidade socioeconômica. Dessa forma, pode-se entender que a finalidade da Feira é vista como um elemento central daquela instituição e das organizações familiares que a compõem, pois esse elemento, a princípio, seria o elo comum e responsável pela união dos diferentes artistas e artesãos num mesmo espaço e com o mesmo objetivo. Essa seria, portanto, a essência da agregação de tais indivíduos e organizações e, logo, um valor compartilhado.

Por último, o tema da influência do espaço revela a importante adequação entre os temas anteriores, influência hippie e finalidade da Feira, pois é por meio desse espaço delimitado que as relações sociais e comerciais são medidas. Além disso, o espaço da praça da Liberdade possui características intrínsecas, como a sua posição geográfica privilegiada, o fato de ser freqüentada por grande parte da população, além de ser uma zona nobre da cidade onde se situa a sede do governo do estado. Tais características são associadas à Feira, na medida em que esse espaço serve de mediação para as relações que são estabelecidas na Feira, conferindo então um caráter de distintividade à mesma, tanto que a mesma é designada por Feira Hippie de Belo Horizonte, ou seja, o aposto especificativo traz consigo o traço subjacente de sua distintiviade.

Em suma, pode-se observar, por meio dos critérios utilizados por Albert e Whetten (1985), que os temas apresentados como a finalidade da Feira estabelecem uma relação direta com a questão da centralidade, ou seja, da essência cultural da instituição, enquanto o tema da influência do espaço da praça da Liberdade ressaltaria sua característica peculiar em relação às demais feiras existentes; ou seja, poderia ser considerado o elemento de distintividade. Por fim, a influência hippie pode ser vista como elemento definidor de uma certa noção de 
origem, das "raízes", da continuidade temporal e das subjetividades que a mantém, sendo inclusive esse o nome popular da Feira mantido até os dias atuais (ALBERT; WHETTEN, 1985).

\section{Subconjunto da clivagem identitária}

No segundo subconjunto, o da clivagem identitária, foram explorados os seguintes temas: a) a influência política na Feira com o tema subjacente do crescimento desordenado; b) a mudança de função, de espaço cultural para comercial; e c) a mudança espacial, da praça da Liberdade para a avenida Afonso Pena. Tais temas se relacionaram interdiscursivamente de modo opositivo ao subconjunto da formação da identidade, uma vez que eles representam a descaracterização da antiga identidade e uma nova caracterização da identidade da Feira.

O primeiro tema abordado nesse subconjunto foi o da influência política, referindo-se à emissão e concessão de pedidos para obtenção de vagas de maneira irregular, ou seja, não passando pelos critérios de seleção elaborados pela comissão técnica consultiva da prefeitura. Esse tema possui como subjacente o tema do crescimento desordenado ou inchaço do evento que é um dos primeiros elementos responsáveis pela descaracterização da Feira.

O fragmento 10 apresenta a influência política na gestão da Feira, pelo tema implícito subentendido do inchaço (crescimento desordenado), por meio da mobilização das seguintes personagens discursivas: 1) "[prefeito] Maurício Campos", que realizou a reorganização espacial da Feira e a expressão "com a virada política" que é, ao mesmo tempo, um aposto explicativo e uma escolha lexical do enunciador, utilizada para designar o implícito pressuposto da personagem implícita "outro prefeito eleito", cuja função foi a de promover o inchaço na Feira; e 2) "expositor", que teria sido prejudicado pela entrada de novos expositores, pelo aumento da concorrência e diminuição do seu espaço físico.

Na oração "onde não havia lugar para um expositor, estão mil" há outro implícito pressuposto, o de que houve a entrada de novos expositores, mesmo não existindo vagas. Além disso, subentende-se que essa entrada seria irregular e estaria vinculada à influência da "virada política", remetendo à personagem implícita "políticos" que deram lugares aos expositores. Porém, o trecho deixa silenciado quem seria responsável pela entrada de novos expositores.

(10) [...] durante a gestão de Maurício Campos à frente da Prefeitura, foi feito um remanejamento, visando organizar a Feira [...] no entanto, com a virada política, onde não havia lugar para um expositor, estão mil. (EDIÇÃO DO BRASIL, 1987)

Já no fragmento 11, a influência política é vista como um problema político, onde o tema implícito do crescimento é explicitado pela seleção lexical "desaguadouro", usada metaforicamente para materializar a quantidade de pedidos de políticos para dar acesso a pessoas (personagem discursiva implícita) na "Feira" (figura discursiva explícita). A seleção lexical "desnaturamento" deixa implícito, de modo pressuposto, a condição de desnaturação, ou seja, de perda de vida e, no sentido figurado, a de perda das condições originais da Feira. Isso é confirmado por outra seleção lexical, "transformada", que deixa implícito, de modo pressuposto, que antes a Feira não era "desaguadouro" de pedidos políticos para obtenção de licenças e ao se transformar em um, ela passa por um processo de "desnaturamento". Assim, como responsáveis por esses pedidos de licenças, surgem as personagens explícitas "vereadores" e "cabos eleitorais", que teriam o papel discursivo de fazerem pedidos irregulares de concessões de licença.

(11) O segundo problema da Feira de Artesanato é político. Seu desnaturamento deve-se, muito, ao fato de ter sido transformada num desaguadouro de pedidos de vereadores e cabos eleitorais dos mais diversos partidos. (MARINA, 1994)

No fragmento 12, reproduzimos um documento oficial da Secretaria de Estado de Esportes, Lazer e Turismo, de onde a personagem "Deputado TANCREDO ANTÔNIO NAVES" expediu seu pedido de obtenção de licença na Feira da Praça da Liberdade, destinado ao "secretário de Turismo", em favor do atendimento de uma possível eleitora. Aqui fica explícito o tema do "clientelismo político", onde a personagem mobilizada "Depu- 
tado TANCREDO ANTÔNIO NAVES" utiliza sua influência como figura pública e portador de poder representativo do povo, marcado pelos traços lingüísticos no texto: o termo "Deputado" e seu nome grafado em maiúsculas e negritado, o que cria um efeito estilístico de persuasão ideológica sobre a personagem do "secretário" a quem o primeiro deseja se impor e ter atendidos os seus desejos. Vale ressaltar que a seleção lexical dos termos "encareço" e "atenção especial", ambos utilizados como eufemismos, respectivamente para o ato de pedir e também, para conseguir uma vaga de forma irregular, implicam o implícito subentendido de que havia uma relação de tráfego de influências entre os órgãos do poder público municipal e estadual.

\section{(12) Senhor Secretário,}

Com atenciosos cumprimentos, venho solicitar-lhe uma licença para a exposição dos trabalhos da artesã (porcelana) GLAÚCIA DE CARVALHO JUNQUEIRA, na Feira da Praça da Liberdade.

Por tratar-se de pessoa amiga e a quem gostaria de poder ajudar, encareço a V. Sa uma atenção especial à pretensão da mesma. [...]

\section{Deputado TANCREDO ANTÔNIO NAVES}

\section{Secretário de Estado de Esportes, Lazer e Turismo. (NAVES, 1987)}

Já o trecho 13 evidencia, além da consolidação do espaço comercial, o tema implícito do "trabalho", a partir do eufemismo da seleção lexical "atenuar a situação do desemprego". Nesse tema, a Feira é vista como portadora de uma função social e econômica. Ela é vista como uma instituição capaz de absorver a mão-de-obra desempregada da cidade de Belo Horizonte. Com base nisso, nota-se que o processo de institucionalização e legitimação da Feira acontece tanto pela prefeitura, que a instituiu no início devido ao seu poder legal, quanto aos seus participantes (expositores e consumidores), que reafirmam a legitimidade do evento através de sua participação. Assim, a legitimação da Feira se dá pela mobilização de várias personagens, como a "sociedade", que se convence; os "produtores", que ganharam um mercado e não têm que arcar com impostos; e o "enorme público" que passou a visitar e a consumir os produtos da Feira.

Assim, termos como "fabuloso mercado", "oportunidade [...] sem ônus para o produtor", "meio de atenuar a situação do desemprego", "custo e preços ínfimos aos produtores" são usados para qualificar o caráter comercial que a Feira passou a assumir. Confirma-se essa posição pela mobilização da personagem "enorme público", a quem é implicitamente subentendido o fato de serem os consumidores desse "fabuloso mercado". Pela expressão "sem ônus" pode-se, implicitamente de modo pressuposto, inferir a natureza comercial do "mercado" da Feira, ou seja, a ausência de impostos. Isso é confirmado pela expressão "de custo e preços ínfimos", onde se subentende que a Feira tornou-se atrativa para a população por causa do preço dos seus produtos que, por sua vez, só poderiam ser baixos em virtude do não pagamento de impostos.

(13) O tempo passava e a sociedade se convencia da necessidade de consolidar ou garantir a realização da Feira, uma oportunidade de alegres encontros dominicais na famosa Praça da Liberdade. A Feira era vista também como um meio de atenuar a situação do desemprego, já grave e crucial naquele momento. Era uma oportunidade de se colocar artefatos de decoração e obras de arte sem o menor entrave burocrático e sem ônus para o produtor. De custo e preços infimos, os produtores da Feira conquistaram um fabuloso mercado. A Feira tornava-se pequena para o enorme público. (MOURA, 1988)

Logo, ao enfrentar um processo de "desnaturação", pela entrada de uma gama de pessoas que não estavam necessariamente vinculadas à questão artística da Feira, mas sim ao seu caráter econômico, ela perde suas características originais. Ela passa por processos de mudanças como, por exemplo, de função. Se antes a Feira era considerada um espaço cultural, agora ela vai aos poucos se tornando um espaço comercial, sendo imprescindível ressaltar que nesse processo de mudança de função - elemento que confere um caráter de centralidade à Feira - há uma sobreposição de funções, no sentido de que a função econômica se torna a mais importante, porém não suprimindo a anterior. 
Dessa forma, a mudança de função é metonimicamente explicitada pela seleção lexical da expressão "peças em série", que passam a substituir o "artesanato mineiro", cujo predicativo é "de qualidade". No trecho 14 são mobilizadas, explicitamente, as personagens Yara Tupinambá, artista que critica as atuais características da figura discursiva "Feira" - onde predomina a produção em série, sem criatividade - e, implicitamente, "as pessoas" que fabricam o artesanato em série.

(14) A Feira de Artesanato da Avenida Afonso Pena, acredita [Yara Tupinambá], virou um grande comércio. "Um enorme camelódromo" [...], entregue a peças feitas em série, sem o menor cuidado criativo. "O que falta é uma identidade cultural [...] Na situação econômica em que estamos, é muito mais cômodo repetir infinitamente os artigos que têm venda garantida. [...] $O$ artesanato mineiro, de qualidade, não tem mais espaços dignos de divulgação." (STÁBILE, 2004)

A metáfora "camelódromo" é uma escolha lexical da personagem Yara - que por sua vez é citada no discurso do enunciador da reportagem, gerando polifonia - para se referir ao "grande comércio", denunciando, assim, de modo implícito subentendido, a mudança de função da Feira: de um espaço cultural para um espaço comercial. A transformação onde predomina o caráter comercial também está presente no explícito "repetir infinitamente os artigos que têm venda garantida", que leva ao implícito pressuposto de que a produção de artigos que não têm venda garantida seria incômoda ou economicamente inviável e de que, portanto, os feirantes passariam a se preocupar apenas com aqueles produtos que tivessem apelo comercial.

Corroborando essa argumentação, o aposto restritivo "de qualidade", referente à figura do "artesanato mineiro", serve como predicado para delimitar qual tipo de artesanato deveria estar na Feira, mas que tem perdido espaço de divulgação. O termo "de qualidade" ainda suscita o implícito pressuposto (por uma relação de conteúdo opositivo ao termo "peças feitas em série") de que o artesanato de qualidade não é aquele feito em série, deixando subentendido que seja aquele feito individualmente.

No trecho 15, a transformação do sentido da Feira cultural para a comercial fica explícita a partir da seleção lexical "perdendo mais terreno", que é, ao mesmo tempo, uma metáfora utilizada pelo enunciador para evidenciar a disputa de um mesmo território/espaço por duas formas distintas e nos casos excludentes de utilização. As ambivalências entre a utilização cultural e comercial, conferidas pelo uso do termo "meramente" para se referir ao uso comercial, atribuem caráter depreciativo a essa forma de utilização do espaço da Feira e deixam implícito pressuposto, a inferioridade do uso comercial. Além disso, fica implícito, subentendido, a adequação da Feira às exigências econômicas, o que contribui para a mudança de suas características identitárias.

(15) Todavia, o sentido cultural que motivou e inspirou a criação das feiras, inclusive aos sábados, está cada dia perdendo mais terreno para o meramente comercial. (TRISTÃO, 1987)

O fragmento 16 também indica uma mudança de função da Feira, ao selecionar o explícito "integrar-se à sociedade de consumo", atribuído à personagem mobilizada "belo-horizontinos" que tem a função de freqüentar as praças, local onde se realizavam as feiras. Também fica explícita a mudança de hábito dos freqüentadores, de passeio grátis ao consumo, o que implica o implícito pressuposto de que a Feira mudou sua função. Dessa forma, surge de modo subjacente ao tema mudança de função da Feira, o tema do consumo visto como uma nova função (entre outras, como a comercial) da Feira, levando o enunciador a mobilizar a personagem discursiva implícita "gestores municipais", a quem é atribuída o papel de "reestudar" a função das feiras.

(16) As feiras devolveram aos belo-horizontinos o costume de freqüentar as praças, uma ou duas vezes por semana, não mais para ver cine grátis, mas para melhor integrar-se à sociedade de consumo. Com o sucesso que obtiveram, aconteceu a invasão. Agora, sua função está sendo reestudada. (MOURA, 1988)

A utilização do termo "invasão", referindo-se à ocupação geral de um lugar por pessoas indesejadas, mobiliza a personagem discursiva implícita "invasores", o que leva ao implícito, pressuposto, de que essas pessoas não faziam parte da Feira e ao mesmo tempo estão se integrando a ela de modo ilegal, invadindo, tomando o "espaço" de forma ilegítima daqueles que estavam na Feira anteriormente. 
A seu turno, a expressão "função reestudada" leva ao implícito pressuposto de que a função já tinha sido estudada antes, e ao implícito subentendido de que a função seria modificada, no sentido de se adequar às novas necessidades ou funções da Feira. Entretanto, o enunciador deixa silenciado quem vai reestudar a função das feiras e quem são os invasores responsáveis por sua mudança.

Já no fragmento 17, em virtude da incorporação de novos tipos de produtores participantes na Feira e, especialmente, devido a sua mudança de local, a Feira sofre uma alteração no seu nome, implícito pressuposto a que se chega pela relação entre conteúdos da Feira de Arte, Artesanato e Produtores de Variedades em oposição à "antiga Feira de Arte e Artesanato". Nesse sentido, o termo "Produtores de Variedades" é colocado no nome oficial da antiga Feira de Artes e Artesanato, com a função de legitimar a nova classe de integrantes da Feira, que não são artistas nem artesãos, mas produtores de variedades. Essa expressão, por sua vez, pode ser vista tanto como uma metáfora quanto uma metonímia. No primeiro sentido, a expressão serve para designar o tipo de feirantes que passaram a fazer parte da Feira, enquanto no segundo sentido, ela evidencia o caráter genérico da atividade. $O$ termo variedades englobaria uma gama de atividades que poderiam ser realizadas, ou seja, o todo, e de maneira específica designaria o comerciante que realizaria aquele tipo de produtos, remetendo, desse modo, à parte.

Nesse trecho, o novo nome expressa a adequação da Feira às novas características e estabelece uma estreita relação com o tema da mudança de função da Feira. Nesse fragmento, o aposto especificativo "quando se transferiu para a avenida Afonso Pena" indica, de modo explícito, a mudança espacial ocorrida na Feira. Ainda como implícito pressuposto, o trecho traz as personagens mobilizadas "artesãos" hoje, que não seriam hippies, nem intelectuais, pois "hoje (a Feira) tem pouco ou quase nada a ver com a antiga [...] Feira Hippie". Já a seleção lexical "pomposamente" pode ser considerada uma ironia relacionando o nome ao conteúdo e aos produtos da Feira.

(17) Batizada pomposamente de Feira de Arte, Artesanato e Produtores de Variedades desde janeiro de 1991, quando se transferiu para a avenida Afonso Pena, a Feira de hoje tem pouco ou quase nada a ver com a antiga Feira de Arte e Artesanato (Feira Hippie como era conhecida, porque seus primeiros artesãos compunham-se de um grupo hippie/intelectual). (ACERVO BELOTUR, 2004)

A mudança espacial também é evidenciada no trecho 18 , onde fica claro sua relação com as injunções políticas ocorridas com o processo de institucionalização da Feira e a mudança identitária. Apreende-se o deslocamento da Feira a partir dos apostos explicativos "inclusive o nome da Feira" e "porque tem determinados setores que você não tem condição de ter um produto $100 \%$ artesanal, vai ter um maquinário, né [...]", que justificam o fato de a Feira ter mudado suas características e, conseqüentemente, justificam também a própria mudança de nome da Feira - que se deu juntamente com a mudança de local. $\mathrm{O}$ enunciador mobiliza a personagem "Feira" que recebe um novo nome onde se percebe, através da seleção lexical "Produtores de Variedades", a geração de um implícito subentendido em que a nova categoria é criada para legitimar os expositores da Feira que não se enquadravam no tipo de produção artesanal antes exigida pela então Feira de Arte e Artesanato.

Vale ressaltar que tais mudanças ocorridas na Feira - de participantes, de características e inclusive de nome culminam com a mudança de espaço físico, uma vez que este não seria mais suficiente para abarcar todos as pessoas que passaram a fazer parte dela. Essa assertiva pode ser inferida, por implícito subentendido, a partir das seleções lexicais "cresceu muito" e "teve que se adaptar" que, também, são usadas para justificar a mudança de nome da Feira.

(18) A Feira mudou muito desde que ela foi constituída em 1969 [...] De lá pra cá, cresceu muito, que a característica da Feira hoje não e só hippie, né, é um ponto turístico da cidade [...] ela teve que se adaptar ao mundo, à tecnologia, à moda, então, muita coisa foi mudando, inclusive o nome da Feira, que era Feira de Artes e Artesanato, aí com esse decreto de 1993, ela passou a se chamar Feira de Artes e Artesanato e Produtores de Variedades, [...]. (Gerente 1, 2004)

Por fim, no fragmento 19 observa-se o aposto explicativo "é claro que rompe com os padrões de uma Feira qualquer" referente ao termo "Isso", que se refere aos termos "30 mil empregos", "100 mil" freqüentadores e ao volume de dinheiro movimentado, "R $\$ 600$ mil por domingo", o que indica por implícito pressuposto o re- 
conhecimento e legitimidade econômica que a Feira adquiriu. Quando ela "rompe com os padrões" de uma Feira qualquer, a Feira hippie tem, portanto, legitimada a sua importância.

Esse argumento é confirmado pelo segundo aposto explicativo "não só uma Feira", que denota implicitamente de modo pressuposto que uma Feira comum tem determinadas características, mas a Feira hippie também possui outras. Como exemplo, podemos citar o volume de negócios que ela gira, o que lhe confere um status além de uma feira comum. Esse "status" vincula-se às figuras utilizadas "centro de abastecimento de mercadorias" e "centro de escoamento de mercadorias" do Brasil e do exterior, onde por meio de implícito pressuposto, extraise a característica distintiva (e legitimadora) da Feira Hippie em relação às demais, ou seja, a sua importância e institucionalização econômicas.

Em "Isso [a transformação da Feira em centro de abastecimento] rompe com a questão da produção em pequena escala, mas não com o caráter artesanal", o verbo "rompe" é uma escolha lexical utilizada para indicar uma desvinculação entre a figura "Feira" e a expressão "produção em pequena escala". Isso acontece ao se transformar em "centro de abastecimento", pois implicitamente, de modo pressuposto, há uma transformação no modo de produção, para que se possa atingir o volume necessitado por esse "mercado" do Brasil e do exterior. Implicitamente, de modo subentendido, percebe-se a questão da adequação da feira aos imperativos da institucionalização que impõem uma mudança direta nas suas características centrais e que lhe conferem identidade, a questão do modo de produção, que passa de artesanal em pequena escala para artesanal em grande escala ou semi industrial. Além disso, infere-se, por implícito subentendido, que esse "rompimento" com os padrões de uma feira qualquer implica também a necessidade de se ter um espaço capaz de sediar um evento de tamanha dimensão, o que explica a mudança de local da Feira de uma praça para uma avenida.

(19) Atualmente estima-se que a Feira gera cerca de 30 mil empregos diretos e indiretos, que cerca de 100 mil pessoas passam por aqui todos os finais de semana, que isso gera um volume de negócios de aproximadamente $R \$ 600$ mil por domingo. Isso, é claro que rompe com os padrões de uma feira qualquer e que faz da Feira Hippie, não só uma feira, mas ela sai da condição de feira e entra para a de mercado de abastecimento e escoamento de produtos para todo o estado, para o Brasil inteiro. Ela se torna um centro de escoamento de mercadorias até no exterior. Isso rompe com a questão da produção em pequena escala, mas não com o caráter artesanal. (Gerente 2, 2004)

Em síntese, observou-se que o tema da influência política, juntamente com o tema subjacente do crescimento desordenado da Feira, levou a uma ruptura com a questão da continuidade temporal da Feira. Tais temas evidenciaram a mudança de valores, de normas de conduta, da própria ideologia que rege as formas de utilização da Feira, seja por parte dos políticos que passaram a fazer dela uma espécie de "curral eleitoral", seja por parte dos comerciantes que passaram a adotar uma "lógica de mercado" para produção e comercialização de seus produtos, em detrimento da antiga lógica de produção e consumo de produtos exclusivos, não-massificados e de consumo racional, que estava vinculada à influência hippie.

A mudança de uma ideologia que garantia uma continuidade temporal à Feira, ocasionada pela entrada de novas pessoas que não tinham nada a ver com a Feira. Eles pertenciam à outra lógica, a da finalidade econômica, e assim provocaram um movimento de desterritorialização das antigas significações construídas historicamente pelos comerciantes naquele espaço físico e simbólico e que, de certa forma, regiam o comportamento deles, levando-os a fazer um movimento de reterritorialização sob uma nova lógica.

Com a mudança de influências - de hippie para política - sobre a Feira, os processos desencadeados por essas mudanças, há uma transição no caráter de centralidade da Feira. Ela muda na sua característica essencial, que antes era tida como sua finalidade cultural. Em um segundo momento, passa a ser considerada como uma finalidade comercial, o que contribui para a modificação da identidade da Feira construída ao longo de sua história. Assim, abre-se caminho para a mudança de função da Feira, que passa a ser vista mais como um local de comércio do que como espaço cultural.

Assim, o sucesso econômico da Feira Hippie, que veio a reboque a partir da sua finalidade cultural, faz com que ela seja reconhecida como um grande centro de produção e comercialização de artigos e produtos que vão corroborar a ideologia capitalista. Embora esse não fosse o foco da Feira no seu início, com a entrada maciça de 
novos feirantes a partir do final da década de 1970 e início da década de 1980, a Feira se torna um grande centro comercial, pois esses novos comerciantes viam na Feira, antes, uma oportunidade comercial, de ganhar a vida, do que um espaço de produção e divulgação da cultura. Aos poucos, a ideologia hippie vai perdendo sua influência, vai perdendo espaço para a construção de uma nova ideologia sobre a Feira como um espaço de consumo e de comércio.

Há um imbricamento entre a questão da influência política (que substitui a hippie), que denota uma mudança do elemento que confere continuidade temporal, e a finalidade, ou elemento que confere a centralidade (essência) da Feira. Por sua vez, a mudança desse último aspecto, ao evidenciar a Feira como um espaço de comércio, que atrai milhares de pessoas para comprar e vender, implica necessariamente uma mudança de local, a fim de comportar toda essa Feira que passa a romper com os padrões de uma feira comum. Mudança essa que também pode ser entendida como uma mudança da sua característica "distintiva", pois antes a praça da Liberdade conferia essa característica à Feira, tanto que ela era denominada Feira da Praça da Liberdade. Hoje, a distintividade se dá de outra forma, por causa dos produtos, do nome, da imagem que se criou a respeito da Feira de Arte, Artesanato e Produtores de Variedades da Avenida Afonso Pena.

Desse modo, a mudança espacial implica um novo critério de distintividade (um novo espaço), bem como as noções de centralidade da instituição, apreendida pela sua mudança de função, que passa a ter caráter socioeconômico. Já o seu critério de temporalidade pode ser relacionado à institucionalização por parte dos diferentes atores sociais, implícito pressuposto a que se chega pelo tema do crescimento desordenado (ALBERT; WHETTEN, 1985).

\section{Considerações finais}

Na busca por alcançar o objetivo de analisar as transformações identitárias ocorridas na Feira de Arte, Artesanato e Produtores de Variedades de Belo Horizonte evidenciou-se a existência de determinadas visões de mundo que compõem as identidades da Feira ao longo de seus 36 anos de existência. Por um lado, o suporte metodológico da análise do discurso (AD) se mostrou pertinente para evidenciar processos fenomenológicos de maneira aprofundada. A AD, no nível intradiscursivo, evidenciou a existência de um conjunto de temas, como a influência hippie, e figuras como a "Feira" (que ora também surge como personagem), que se relacionam com a construção da identidade organizacional (ou institucional) da Feira em um dado contexto.

Evidenciou-se também pela AD o conjunto de estratégias de persuasão utilizadas pelos enunciadores como, por exemplo, a criação dos personagens "verdadeiros artesãos" (e por implícito pressuposto, os "falsos artesãos"), e como esses processos evidenciam a construção de identidades organizacionais em determinados contextos. Essas estratégias se materializaram na produção do discurso, de acordo com seu contexto, revelando uma dada visão de mundo, um conjunto de representações sobre o que é ou deveria ser a Feira, ou seja, a sua identidade.

Além disso, foi possível revelar como essa visão de mundo se transformou pela incorporação de novos membros portadores de outras "visões" dentro do mesmo espaço físico e simbólico. Isso, por sua vez, cria um movimento de ruptura com os "valores" antigos e, com o tempo, passa a se tornar a visão "dominante", revelando, assim, um processo de transformação identitária. Nesse sentido, a AD possibilitou aos pesquisadores a compreensão das ideologias existentes nos discursos, no âmbito interdiscursivo (FARIA, 2001). Assim, por exemplo, no discurso do fragmento (03) o enunciador nega a influência hippie, embora reconheça a existência da personagem "hippies" antes da criação da Feira, estabelecendo interdiscursivamente uma relação de oposição com o fragmento 01, no qual tal personagem (os hippies) é responsabilizada pela origem da Feira.

Por outro lado, pode-se observar que a transformação de identidade, evidenciada pelo estudo do percurso semântico, possibilitou a compreensão desse fenômeno social ao considerar a identidade organizacional da Feira como resultante de um conjunto de "representações compartilhadas" pelos seus diversos atores sociais (MACHADO, 2005, p.3). Essas representações estão intimamente vinculadas ao espaço físico e à representação deste no plano simbólico. Pela noção de identidade como conjunto de representações dos membros, podemos inferir que tais representações estão ligadas e são suscetíveis a variações ocorridas no grupo social. Variações essas que, no caso, mostraram-se em termos de quantidade de indivíduos, representantes de organizações 
produtivas familiares, que passaram a fazer parte da Feira, ou seja, no tamanho do grupo de atores que compunham aquela instituição.

A mudança identitária ocasionada pelo aumento do número de membros pode ser observada no subconjunto da clivagem identitária - por meio do tema da influência política - que o crescimento desordenado da Feira foi o responsável direto pelos primeiros sinais de descaracterização de suas funções originais. Ressalta-se que a influência política apresentou-se como responsável dessa descaracterização. Tal processo é explicitado pelos fragmentos 11, o qual se refere ao fato da Feira ter sido "transformada num desaguadouro de pedidos de vereadores e cabos eleitorais dos mais diversos partidos", e 16, o qual atribui o crescimento da Feira ao fato dela ter mudado (inclusive) de nome e de espaço, a fim de se adequar. Assim, estabelece-se uma relação dinâmica entre identidade (compartilhada por membros) e espaço, pois a maior concentração de pessoas no mesmo espaço físico da Feira influiu de modo significativo na entrada de pessoas com novas percepções do evento. Desse modo, vendo-o não mais pela sua característica cultural de expressão da arte, mas como um espaço "meramente comercial", de venda, de lucro, que poderia ser considerado como fonte de renda.

Albano et al (1984) ressaltam a relação entre a dinâmica do espaço e a identidade dos grupos sociais que o constroem e reconstroem, atribuindo-lhe novos usos e significados. O processo ocorre por meio do poder delegado às pessoas encarregadas de dirigir a Feira ou pela subversão do uso das pessoas e, conseqüentemente, redefinição das funções do espaço, intrinsecamente relacionado a um conjunto de significações simbólicas. Desse modo, a incorporação de novas pessoas, com novas identidades e "representações compartilhadas" sobre a Feira gerou, nesse espaço, uma ruptura da antiga identidade (ORTIZ, 1994) e possibilitou as bases para a construção de uma nova identidade, identidade essa (con)formada a partir das novas representações dos membros sobre o novo espaço da Feira e sua nova função, que passa a ser tida como "meramente econômica".

A questão da identidade pode ser vista como definidora da ordem espacial ao servir de base para a construção de racionalizações sobre sua função e uso. Isso ocorre na mesma medida em que é influenciada por essa disposição espacial e seus constantes movimentos de (re)estruturação, de territorialização e desterritorialização por parte de grupos sociais. Assim, ao evidenciarmos a mudança das ideologias, das racionalizações que atribuem, justificam e legitimam a forma pela qual os indivíduos se relacionam com um determinado espaço, evidenciase, também, que a constituição de um espaço de consumo implica um consumo do espaço, onde os indivíduos passam a subverter a ordem preestabelecida, na medida em que (re)constroem suas identidades para justificarem e legitimarem o novo modo de se relacionar com o espaço e entre si.

Contudo, se por um lado este estudo evidencia que a construção de identidades se mostra relacionada com o espaço (físico e simbólico), por outro, não se deve considerar apenas os parâmetros de análise da identidade organizacional propostos por Albert e Whetthen (1985), pois, apesar de serem de grande utilidade, na medida em que servem como um guia de referência para a análise de identidades, eles não são suficientes para explicar o fenômeno em questão, uma vez que as identidades mudam contextualmente. Portanto, a rigor, não haveria elementos centrais, distintivos e, muito menos, duradouros, salvo se contextualizados em uma dada conjuntura histórica sujeita a constantes revisões e alterações. Tais elementos não são estruturais, fixos, imutáveis e independentes de quaisquer condições, pelo contrário, são contingenciais e só fazem sentido em um dado contexto sociocultural e histórico. Isso só foi possível de se apreender a partir da AD que permite enxergar de modo acurado tais conjunturas e as ideologias, - que mantém legitimam determinadas concepções e orientam determinadas formas de ação - subjacentes à rede de discursos que compõem a produção textual daquela conjuntura histórica. Nesse sentido, ela complementa a análise do fenômeno estudado preenchendo as lacunas que antes não poderiam ser observadas.

Por fim, podemos concluir que o entendimento da identidade, como dimensão simbólica-cultural, historicamente construída (NKOMO; COX JUNIOR,1996), contextual (BORZEIX; LINHART, 1996) e definida por um sistema de significações (FIOL; HATCH; GOLDEN-BIDDLE, 1998; SCHULTZ; HATCH; LARSEN, 2000), está intimamente relacionado ao espaço, sendo em parte revelado pelo estudo deste, pois no espaço ocorre a "manifestação concentrada de uma ordem simbólica [...] [que] não é um dado, é dinâmica, inserida na história, é espaço de síntese" (ALBANO et al., 1984). Portanto, ao se estudar o espaço, físico e simbólico, deve-se observar a forma e a função de cada um deles, suas interações com a questão temporal e a maneira se- 
gundo a qual nele se evidenciam as formas de racionalizações, de pensar e agir de determinados grupos e as contradições inerentes aos mesmos ao longo do tempo. 


\section{Referências}

ACERVO BELOTUR - Empresa municipal de Turismo de Belo Horizonte. Feira das feiras mantém o charme. Belo Horizonte, 2004.

ALBANO, C. et al. A cidade na praça: poder, memória, liberdade. In: REUNIÃO DO GT ESTUDOS URBANOS: REPRESENTAÇÕES E POLITICAS PÚBLICAS, Águas de São Pedro, SP, 24-26 out. 1984.

ALBERT, S.; WHETTEN, D. A. Organizational identity. Research in Organizational Behavior, London, v.7, p.263-295, 1985.

ARANHA, P. 0 objetivo era popularizar a arte em BH. Estado de Minas, Belo Horizonte, 26 ago. 1994. Segunda seção.

BELO HORIZONTE. Prefeitura Municipal, Superintendência de Turismo. Regulamento da Feira de Arte e Artesanato. Belo Horizonte, 20 ago. 1972. p.1-4.

BELO HORIZONTE. Secretaria Municipal de Cultura, Turismo e Esportes, Departamento de Turismo, Setor de Feiras. Ata da reunião de constituição da comissão especial para revisão administrativa das feiras de arte e artesanato de Belo Horizonte. Belo Horizonte, 31 out. 1979. p.1.

BELO HORIZONTE. Prefeitura Municipal. Administração Regional Centro-Sul. Programa de Reorganização das Feiras de Arte e Artesanato da Região Centro-Sul de Belo Horizonte. Belo Horizonte, jan. 1991.

BELOTUR - Empresa Municipal de Turismo de Belo Horizonte. Circular interna sobre a situação da Feira de Arte e Artesanato da Afonso Pena: excelente programa para as manhãs de domingo em BH. Belo Horizonte, 2004. p.1-2.

BORZEIX, A.; LINHART, D. Identidades e práticas lingüisticas na empresa. In: CHANLAT, J.-F. (Org.). 0 indivíduo na organização: dimensões esquecidas. São Paulo: Atlas, 1996. v.III, p.82-106.

CALDEIRA, J. M. Praça: território de sociabilidade, uma leitura sobre o processo de restauração da Praça da Liberdade em Belo Horizonte (MG). 1998. Dissertação (Mestrado) - Universidade Estadual de Campinas, 1998.

CARRIERI, A. de P. O Fim do "Mundo Telemig": a transformação das significações culturais em uma empresa de telecomunicações. Tese (Doutorado em Administração) -Universidade Federal de Minas Gerais, Belo Horizonte, 2001. 326f.

CERTEAU, M. L'invention du quotidien - 1'arts de faire. Paris: Editions Gallimard, 1990.

CHANLAT, J. F. Por uma antropologia da condição humana nas organizações. In: CHANLAT, J.-F. (Org.). 0 individuo na organização: dimensões esquecidas. São Paulo: Atlas, 1992. v.l, p.21-45.

CORRÊA, R. L. Territorialidade e corporação: um exemplo. In: SANTOS, M.; SOUZA, M. A. A.; SILVEIRA, M. L. (Org.). Território: globalização e fragmentação. São Paulo: Hucitec/Anpur, 1996.

EDIÇÃO DO BRASIL. 30 mil pessoas vivem da renda da Feira da Praça. Belo Horizonte, 5-12 abr. 1987. Reportagem local. (Arquivo pessoal de Lídice Tristão).

FARIA, A. A. M. Interdiscurso e intradiscurso: da teoria à metodologia. In: MENDES, E A.; OLIVEIRA, P. M.; BENN-IBLER, V. (Org.). 0 novo milênio: interfaces lingüísticas e literárias. Belo Horizonte: Fale/UFMG, 2001.

; LINHARES, P. T. F. S. 0 preço da passagem no discurso de uma empresa de ônibus. In: MACHADO, I. L. (Org.). Análises de discursos: sedução e persuasão. Belo Horizonte: NAPq Fale/UFMG, 1993. (Caderno de Pesquisa n.13).

FÁVERO, L. L. Paródia e dialogismo. In: BARROS, D. L. P.; FIORIN, J. L. (Org.). Dialogismo, polifonia, intertextualidade. São Paulo: Editora da Universidade de São Paulo, 2003. p.49-61.

FERRETTI, M. Feiras Nordestinas - Estudos e problemas. In: FERRETII, S. (Org.). Reeducando o olhar: estudos sobre feiras e mercados. São Luis, Maranhão: Edições Universidade Federal do Maranhão/Proin-CS, 2000. p.36-66.

FIOL, M.; HATCH, M. J.; GOLDEN-BIDDLE, K. Organizational culture and identity: what's the difference anyway? In: WHETTEN, D. A.; GODFREY, P. C (Ed.). Identity in organizations: building theory through conversations. London: Sage, 1998. p.56-62.

FIORIN, J. L. Linguagem e ideologia. São Paulo: Ática, 1988.

FREITAS, M. E. Cultura organizacional: identidade, sedução e carisma? Rio de Janeiro: FGV, 1999.

GUATTARI, F. Micropolítica: cartografia do desejo. Petrópolis: Vozes, 1986. 
GUERRA, L. C. O. Imagens de um território urbano. 2002. 115f. Dissertação (Mestrado) - Instituto de Geociências, Universidade Federal de Minas Gerais, 2002.

HARVEY, D. A condição pós-moderna. São Paulo: Loyola, 1992.

HATCH, M. J.; SCHULTZ, M. Scaling the tower of babel: relational differences between identity, image and culture in organizations. In: SCHULTZ, M.; HATCH, M. J.; LARSEN, M. H. The expressive organization: linking identity, reputation and the corporate brand. New York: Oxford University Press, 2000. 272p.

MACHADO, H. V. Identidade organizacional; um estudo de caso no contexto da cultura brasileira. RAE-Eletrônica, v.4, n.1, art. 12, jan./jul.2005.

; KOPITKE, B. A identidade no contexto organizacional: perspectivas múltiplas de estudo. In: ENCONTRO DE ESTUDOS ORGANIZACIONAIS (Eneo), 2, 2002, Recife. Anais... Recife: Anpad, 2002.

MAINGUENEAU, D. Termos-chave da análise do discurso. Belo Horizonte: Ed. UFMG, 1998.

MARINA, A. Problemas da Feira de Artesanato. Estado de Minas, Belo Horizonte, 28 ago. 1994. Segunda Seção, p.2.

MOURA, A. P. As feiras da Praça da Liberdade: pequena história de um evento que deu certo em BH. Estado de Minas, Belo Horizonte, 3 maio 1988. Segunda Seção.

MUMBY, D. K; CLAIR R. P. Organizational discourse. In: VAN DIJK (Org.). Discourse as Social Interaction. London: Sage. 1997. p.181-205.

NAVES, T. A. Governo do Estado de Minas Gerais. Secretaria de Esportes, Lazer e Turismo. Gabinete do Secretário. Ofício n.571/87. Belo Horizonte, 11 maio 1987.

NKOMO, S. M.; COX JUNIOR., T. Diverse identities in organizations. In: CLEGG, S. R.; HARDY, C.; NORD, W. (Ed.). Handbook of Organization Studies. London: Sage, 1996. p.338-356.

NOGUEIRA, E.E.S.R. Cultura e identidade organizacional: estudo de caso do sistema aduaneiro brasileiro. 2000. Dissertação (Mestrado em Administração) - Setor de Ciências Sociais Aplicadas, Universidade Federal do Paraná, Curitiba, 2000.

ODILLA, F. Tombamento da Feira da Afonso Pena. Estado de Minas, Belo Horizonte, 17 dez. 2004. Caderno Gerais, p.21.

ORTIZ, R. Mundialização e Cultura. São Paulo: Brasiliense, 1994.

PAGÉS, B. M.; GAULEJAC, V.; DESCENDRE, D. 0 poder das organizações: a dominação das multinacionais sobre os indivíduos. São Paulo: Atlas, 1987.

PRAT, M. G.; FOREMAN, P. 0. Classifying managerial responses to multiple organizational identities. Academy of Management Review, v.25, n.1, p.18-42, jan. 2000.

RUCKHYS, A. A. A interface ecoturistica em reportagens da revista Os Caminhos da Terra. Belo Horizonte, 2003. Dissertação (Mestrado) Programa de Pós-Graduação em Estudos Lingüisticos (PosLin) Análise do Discurso, Fale/UFMG. Belo Horizonte, 2003.

RODRIGUES, S. B. Cultura corporativa e identidade: desinstitucionalização em empresa de telecomunicações brasileira. Revista de Administração Contemporânea, Curitiba, v.1, n.2, p.45-72, 1997.

; CARRIERI, A. P., LUZ, T. R. A construção de uma pesquisa em grupo In: RODRIGUES, S. B., CARRIERI, A. P., LUZ, T. R. (Org.).Tempos de desconstrução: evolução e transformação nas empresas. 1.ed. Belo Horizonte: Cepead/Face/UFMG, 2003, v.1, p.13-17.

ROWLINSON, M.; PROCTER, S. Organizational culture and business history. Organization Studies, Berlin, v.20, n.3, p.369-396, 1999.

SCHULTZ, M., HATCH, M.J., LARSEN, M.H. The expressive organization: linking identity, reputation and the corporate brand. New York: Oxford University Press, 2000. 272p.

SOUZA, A M. Feira livre na Cohab. In: FERRETTI, S. (Org.). Reeducando o olhar: estudos sobre feiras e mercados. São Luis, Maranhão: Edições Universidade Federal do Maranhão/ Proin-CS, 2000, 190 p.

STÁBILE, L. Feira sem arte: feiras de artesanato da Avenida Afonso Pena e Mineirinho perdem criatividade e expõe produtos industrializados que retiram espaço dos verdadeiros artistas populares. Estado de Minas, Belo Horizonte, 8 jun. 2004. Caderno Gerais.

TRISTÃO, M. Lauda para redação. Diários e Emissoras Associados, 1987. (Arquivo pessoal de Lídice Tristão, coletado em 2004). Documentado manuscrito enviado para o jornal supracitado. 
VASCONCELOS, I. F. F. G.; VASCONCELOS, F. C. Identidade e mudança: o passado como ativo estratégico. In: Enanpad, 24., 2000, Curitiba. Anais... Curitiba: Cromos Editora, 2000. CD-ROM.

Identidade, legitimação social e teoria organizacional: contribuições de uma análise sociológica da política de gestão de pessoas da Natura. Organizações \&t Sociedade, v.10, n.27, maio/ago. 2003.

VILAÇA, W. P. T. Construções identitárias em um processo de aquisição. 2003. 122f. Dissertação (Mestrado) - Programa de Pós-Graduação em Administração, Pontifícia Universidade Católica de Minas Gerais, Belo Horizonte, 2003.

* Este artigo teve sua primeira versão enviada ao XXIX Encontro da Anpad. Nesse sentido, ele constitui um aprimoramento, na medida em que incorpora as críticas e sugestões propostas pelos avaliadores.

${ }^{1}$ Guerra (2002, p. 115) estabelece as diferenças entre "espaço", "lugar" e "território". Enquanto o espaço pode ser considerado uma "área qualquer", o lugar remete a um local definido, específico, possuidor de determinadas referências e/ou significados para alguém. Ele é dotado de subjetividade humana. Por sua vez, o território denota uma relação de posse, em que alguém se apropria de um determinado espaço, dominando-o e subjugando-o segundo sua vontade. Nessa acepção, entende-se que todo território possui fronteiras, entendidas como "aquilo que está à frente" e que é, também, um lugar de passagem, de transição e de limites, que se diferem daquelas, por ser "aquilo que mantém coesa uma unidade territorial".

${ }^{2}$ Segundo Fiorin (2003, p.24), "[...] Tema é o elemento semântico que designa um elemento não-presente no mundo natural, mas que exerce o papel de categoria ordenadora dos fatos observáveis. São temas, por exemplo, amor, paixão, lealdade e alegria. Figura é o elemento semântico que remete a um elemento do mundo natural: casa, mesa, mulher, rosa etc. A distinção entre ambos é, pois, de maior ou menor grau de concretude".

${ }^{3}$ Para Faria (2001, p.32), "o conceito de percurso semântico engloba os conceitos greimasianos de percurso temático e percurso figurativo, por se tratarem ambos de revestimentos - mais abstratos ou mais concretos, respectivamente - de estruturas narrativas".

${ }^{4}$ Para Maingueneau (2000, p.67-68) o discurso remete à noção de formação discursiva, incorporada nos estudos de linguagem por Foucault (1969), no sentido de "[...] designar conjuntos de enunciados relacionados a um mesmo sistema de regras historicamente determinadas".

${ }^{5} \mathrm{O}$ interdiscurso pode ser compreendido como constituído de oposições que um discurso mantém em relação aos demais discursos de um universo discursivo, como o "[...] conjunto dos discursos com os quais uma formação discursiva mantém relação." (RUCKHYS, 2003, p.11). Já o conceito de intradiscurso está ligado "[...] à visão de mundo que o discurso defende, ela pode ser descrita a partir dos percursos semânticos encontrados no intradiscurso, ou seja, nos textos que materializam o discurso dado." (FARIA, 2001, p.32).

${ }^{6}$ Alguns documentos, como os da Prefeitura Municipal de Belo Horizonte (1991), consideram que a Feira teve três momentos distintos. Entretanto, devido à distância temporal entre a publicação de tais documentos e este estudo, torna-se imperativo o acréscimo de mais um período (de 1992 até os dias atuais).

${ }^{7}$ Segundo Fávero (2003, p.50), polifonia pode ser entendida como "[...] multiplicidade de vozes e consciências independentes e distintas que representam pontos de vista sobre o mundo". 